\title{
MERCURIAL FUMIGATION
}

IN THE

\section{TREATMENT OF SYPHILIS.}

BY

HENRY LEE,

SURGEON TO THE RING'S COLLEGE HOSPITAL, AND TO THE LOCK hOSPITAL.

Received June 23d.-Read June 24th, 1856.

Soon after the recognition of the venereal disease in Europe at the end of the fifteenth century, fumigations of various sorts were employed in its treatment. Among these mercurial fumigations soon held the first rank. But the want of precise knowledge of the nature of the substances used, rendered this mode of treatment liable to serious inconveniences; and the cumbrous nature of the apparatus employed, tended still more to bring it into disuse. Accordingly, the employment of fumigations in venereal diseases was discontinued, so soon as other modes of treatment more certain in their results, and of more easy application, were discovered. During a period of three centuries following, the attempts made to introduce mercurial fumigations were not more successful, owing to the want of care in their employment, and the defective nature of the apparatus used.

In 1776, the Chevalier Lalonette published what he 
called a new method of treating the venereal disease by fumigations. His method consisted in placing the patient in a closed box, from which the patient's head projected, so as to allow the mercurial vapour to act upon the whole surface of the body, while the respiration was not interfered with. The mercurial preparation used was a kind of calomel, which, by repeated sublimation with iron filings, was so far deprived of its muriatic acid as to be in part reduced into running quicksilver. ${ }^{1}$ This preparation was placed on a heated metallic plate at the bottom of the box, and was immediately converted into smoke, which surrounded the patient's body.

The mode of preparing this powder was troublesome and expensive. Abernethy made it in a much more simple way by adding two drachms of liquor ammoniæ to six ounces of distilled water. Four ounces of calomel were then thrown into this mixture, and the whole shaken up together. The powder was afterwards separated by a filter and dried. It was then of a gray colour, and contained a good deal of quicksilver in its metallic state.

Mr. Pearson tried Lalonette's apparatus. He found that the patient's gums became turgid and tender very quickly, and that the local appearances of disease were sooner removed than by the other modes of introducing mercury into the system. The quantity of mercury used, rather than its effect on the patient's system, was considered, in Mr. Pearson's day, as the essential circumstance to be regarded in the treatment of syphilis ; and accordingly he remarks :- "it is extremely difficult to introduce a sufficient quantity of mercury into the animal frame (by fumigation) so as to secure the patient against the hazard of a relapse."2

In attempting to introduce the quantity imagined to be requisite, Mr. Pearson found " that it induced a considerable debility in a short space of time, that a ptyalism was often excited rapidly ;" and that, consequently, the remedy which

1 Abernethy's 'Surgical and Physiological Essays.'

2 Pearson's ' Observations on the Lues Venerea,' p. 123. 
acted so powerfully on the animal frame had often to be discontinued.

The fumigating machine used by Lalonette, Mr. Pearson regarded as a very convenient one, but as no novel invention, as it differed in no material circumstance from that described by Nicholas de Blegny, in the year 1683.

In 1824, M. Rapou published two volumes on fumigations as employed in various diseases. The mercurial preparations which he recommends are-lst, cinnabar; 2d, Lalonette's mercurial powder, which consists of a mixture of mercury. and clay ; 3d, calomel ; and, 4th, corrosive sublimate.

The quantity used of the three first he recommends to be from " a quarter to half an ounce each time." That of the last, he says, should not exceed five or six grains, and may be volatilized with the vapour of water by means of a modification in the fumigating apparatus. M. Rapou had only witnessed salivation produced in three instances, and these were of a very short continuance, and yielded to the use of ordinary baths. He recommends, in certain cases, the mercurial fumigations to be used with steam which, as he says, calms the system, softens the skin, and does not prevent the absorption of the mercury (vol. ii, p. 395).

All the methods of applying the mercurial vapour above noticed required the use of an apparatus, and were, consequently, attended by expense and loss of time. For these and other reasons before mentioned, the mode of treatment never became general. It has, however, again been revived within the last few years in a way in which its effects are easily regulated, and which requires no apparatus that every one cannot generally command. Mr. Langston Parker recommends that the patient should be placed on a chair, and covered with an oil-cloth, lined with flannel, and supported by a proper framework. Under the chair are placed a copper bath, containing water, and a metal plate on which is put from one to three drachms of the bisulphuret of mercury, or the same quantity of the gray oxide or the 
binoxide. Under each of these a spirit-lamp is placed. The patient is thus exposed to the influence of three agents;heated air, common steam, and the vapour of mercury, which is thus applied to the whole surface of the body in a moist state.

Practically the inconvenience of this mode of treatment arises from the gray oxide being of very uncertain composition, as procured at the shops; and from the bisulphuret being often adulterated. Moreover, both these preparations require more heat than is furnished by a common spiritlamp for their conversion into vapour.

The preparation usually kept by chymists as the gray oxide, is the protoxide, and is of a greenish or blue colour. When heat is applied to this, it becomes converted into the red deutoxide; and if the heat be further increased, the oxygen is driven off, and the metallic mercury either left, or raised in vapour. The action of this substance is uncertain and unsatisfactory. A preparation under the same name, of a lighter or gray colour, may be obtained from some chymists, which volatilizes well at the ordinary temperature of a common spirit-lamp, and produces its effect with much certainty upon the patient's constitution. The gray colour of this powder depends upon the admixture of a certain proportion of calomel with the protoxide; and the comparative low temperature at which it volatilizes depends upon the same cause. If this last preparation could always be procured, containing the same amount of calomel, it would answer very well for the purpose of mercurial fumigation; but obtained at different shops, and even at different times at the same shop, it is found to vary materially in its composition.

Finding from experience that it was the light coloured oxide alone which volatilized, and produced its effects upon the patient's constitution, and having reason to believe that the light colour depended upon the presence of calomel, I performed a series of experiments with calomel alone, or mixed in a certain proportion with the gray oxide. The 
general result of these experiments has been, to satisfy me that, for the purposes of mercurial fumigation, five or ten grains of calomel alone is, in ordinary cases, quite sufficient; and that when the gray oxide is used, the admixture of a few grains of calomel will facilitate its sublimation, and insure its medicinal action.

In Lalonette's apparatus, according to M. Rapou (vol. i, p. 40), the mercury was raised in a metallic state (the gray oxide being first converted into a deutoxide, and the oxygen then being in great part or altogether driven off). The preparation used was therefore of uncertain composition, and its effects must necessarily have varied also. Now calomel is not acted upon either by heat or the vapour of water, and, consequently, can be used with comparative certainty both as regards its composition when volatilized, and its physiological effects.

Upon making comparative trials with the calomel alone and combined with steam, it was found to act more certainly and with greater regularity in the latter case.

The plan which I have adopted is very simple. Two small lamps are procured in which the methylated spirit (much cheaper than spirits of wine) is used; over the first lamp is a thin metallic plate, upon which the ten grains of calomel are placed; over the second lamp is a small cup of hot water. A small cane bottomed chair is placed over the lamps, and the patient sits upon it. He is then enveloped, chair and all, in a blanket; at the expiration of a quarter of an hour or twenty minutes he rolls himself up in the blanket and goes to bed.

For patients to whom it may not be convenient to procure the spirit-lamps, the mode of proceeding may be varied as follows: The patient is directed to heat a thick tile in the fire; this is then put into a night-stool, and a gallipot full of warm water placed upon one corner of it. The calomel powder is then sprinkled over the rest of the tile, and the patient sits over it, being enveloped, as before, in a blanket. This mode of applying the vapour is very con- 
venient in cases of affections, either primary or secondary, of the generative organs. It is not necessary in either case that the patient should breath the mercurial fumes. It is remarkable how soon the patients' systems are brought under the influence of the mercury by this simple means; and, according to my experience, how effectually it acts in cases both of primary and secondary syphilis. Its great advantage, however, consists in the very little constitutional disturbance produced, and in the avoidance of those symptoms of irritation and debility, both mental and physical, which the prolonged internal use of mercury is so apt to occasion. The mercurial action, when the medicine is introduced through the skin, may be continued for nearly any length of time that may be necessary; and may be repeated as often as may be convenient, without injuring the patient's constitution.

The small quantity of calomel which it is requisite to use at each fumigation, is probably one reason why mercury in this form may be used with such comparative impunity.

The following table presents a view of the first cases in which the gray oxide alone, and in combination with calomel, and calomel alone, were made the subject of comparative experiment. 
'TABLE of Cases of Syphilis treated by Mercurial Fumigation in the Lock Hospital.

\begin{tabular}{|c|c|c|c|c|c|}
\hline No. & 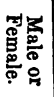 & Age. & Disease. & $\begin{array}{l}\text { Preparation and Quantity } \\
\text { of Mercury Used. }\end{array}$ & $\begin{array}{l}\text { Time at which } \\
\text { Mouth became } \\
\text { affected by the } \\
\text { Fumigation. }\end{array}$ \\
\hline 1 & M. & 30 & $\begin{array}{l}\text { Secondary syphilitic } \\
\text { disease. }\end{array}$ & $\begin{array}{l}\text { Gray oxide, probably } \\
\text { two drachms. }\end{array}$ & $\begin{array}{l}\text { Mouth very } \\
\text { sore with three } \\
\text { fumigations. }\end{array}$ \\
\hline 2 & M. & 29 & $\begin{array}{l}\text { Secondary syphilitic } \\
\text { disease. }\end{array}$ & Gray oxide. & 5 days. \\
\hline 3 & M. & 34 & Tertiary syphilis. & Gray oxide. & 4 days. \\
\hline 4 & M. & 23 & Secondary syphilis. & $\begin{array}{c}\text { Gray oxide, two } \\
\text { drachms every night. }\end{array}$ & s. \\
\hline 5 & M. & 21 & Secondary syphilis. & Gray oxide. & 4 days. \\
\hline 6 & M. & 26 & Syphilitic lepra. & Gray oxide. & 4 days. \\
\hline 7 & M. & 22 & $\begin{array}{l}\text { Syphilitic tubercles } \\
\text { and blotches. }\end{array}$ & Gray oxide. & 8 days. \\
\hline 8 & M. & 28 & Tertiary syphilis. & $\begin{array}{c}\text { Calomel, } 15 \text { grains, } \\
\text { every night. }\end{array}$ & 7 days. \\
\hline 9 & M. & 46 & $\begin{array}{l}\text { Secondary eruption ; } \\
\text { tubercle. }\end{array}$ & Calomel, 15 grains, & 6 days. \\
\hline 10 & M. & 20 & $\begin{array}{l}\text { Indurated primary } \\
\text { sores. }\end{array}$ & $\begin{array}{c}\text { Calomel, } 15 \text { grains, } \\
\text { every night. }\end{array}$ & 2 days. \\
\hline 11 & M. & 25 & $\begin{array}{l}\text { Indurated primary } \\
\text { sore. Secondary erup- }\end{array}$ & $\begin{array}{l}\text { Calomel, } 10 \text { grains, } \\
\text { every night. }\end{array}$ & 10 days. \\
\hline 12 & M. & 28 & $\begin{array}{l}\text { tion. } \\
\text { Tertiary syphilis. }\end{array}$ & $\begin{array}{c}\text { Calomel, } 5 \\
\text { every night. }\end{array}$ & 8 days. \\
\hline 13 & M. & 31 & $\begin{array}{l}\text { Affection of lungs } \\
\text { succeeding secondary } \\
\text { syphilis. }\end{array}$ & $\begin{array}{l}\text { Calomel, } 5 \text { grains, } \\
\text { every night, }\end{array}$ & 4 days. \\
\hline 14 & M. & 29 & $\begin{array}{l}\text { Scaly secondary } \\
\text { eruption. }\end{array}$ & $\begin{array}{l}\text { Calomel, } 5 \text { grains ; } \\
\text { and gray oxide,10 grains: } \\
\text { every night. }\end{array}$ & 2 days. \\
\hline 15 & M. & 22 & $\begin{array}{l}\text { Condylomata on } \\
\text { scrotum and thighs. }\end{array}$ & $\begin{array}{l}\text { Calomel, } 10 \text { grains, } \\
\text { every night. }\end{array}$ & 6 days. \\
\hline 16 & M. & 22 & $\begin{array}{l}\text { Indurated primary } \\
\text { sore. Syphilitic pso- }\end{array}$ & $\begin{array}{l}\text { Calomel, } 10 \text { grains, } \\
\text { every night. }\end{array}$ & 6 days. \\
\hline 17 & F. & 20 & $\begin{array}{l}\text { Praris. } \\
\text { Primary syphilis. }\end{array}$ & $\begin{array}{l}\text { Calomel, } 15 \text { grains, } \\
\text { every night. }\end{array}$ & 5 days. \\
\hline 18 & F. & 19 & $\begin{array}{l}\text { Primary syphilis; } \\
\text { condylomata. }\end{array}$ & $; \begin{array}{c}\text { Calomel, } 10 \text { grains, } \\
\text { every night. }\end{array}$ & 4 days. \\
\hline 19 & F. & 19 & $\begin{array}{l}\text { Indurated primary } \\
\text { sore. }\end{array}$ & $\begin{array}{l}\text { Calomel, } 5 \text { grains : } \\
\text { and gray oxide, } 10 \text { grains, } \\
\text { every night. }\end{array}$ & 4 days. \\
\hline 20 & F. & 16 & $\begin{array}{l}\text { Indurated sore ; con- } \\
\text { dylomata. }\end{array}$ & $\begin{array}{c}\text { Calomel, } 10 \text { grains, } \\
\text { every night. }\end{array}$ & 8 days. \\
\hline
\end{tabular}


To prolong this table would be only to repeat the evidence upon the same point which subsequent experience in a large number of cases has fully established; namely, that a patient's system can be as readily influenced by a small quantity of calomel in vapour as by a large quantity of the gray oxide, or of the bisulphuret of mercury.

In consequence of the calomel not being liable to be decomposed either by heat, or by the vapour of water, its action is comparatively constant, and its influence upon a patient's system may be regulated with great nicety. From the small quantity used, there is little fear of producing salivation, while its effects upon syphilitic disease, in its various forms, are all that can be expected from any mode of treatment by mercury. The essential difference in the mode of using the vapour of calomel now recommended, and any former trials, that have been made, with this preparation, consists in the temperature used for the purpose of volatilizing it. If the temperature be high, as is necessary in other forms of mercurial fumigation, the whole of the calomel is at once converted into vapour. and dissipated in a few moments. At a lower temperature, which can be much more easily obtained in private houses, the operation is prolonged, and time afforded for the vapour to produce its effect upon the skin. 